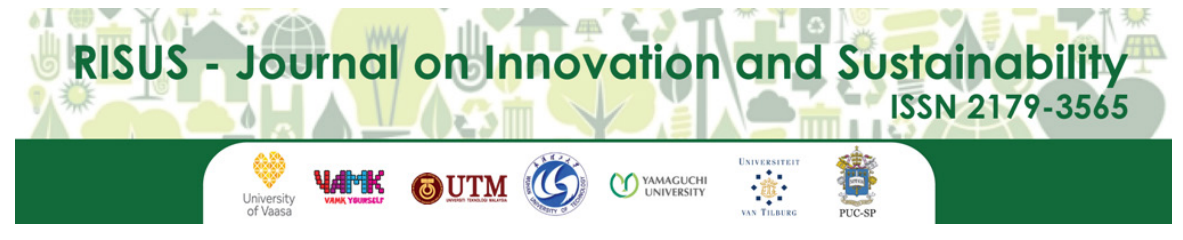

RISUS - Journal on Innovation and Sustainability volume 8 , número 2 - 2017

ISSN: $2179-3565$

Editor Científico: Arnoldo José de Hoyos Guevara Editora Assistente: Lívia Lopes Aguiar

Avaliação: Melhores práticas editoriais da ANPAD

\title{
SUSTAINABILITY IN THE AUTOMOTIVE SECTOR: AN ANALYSIS OF STRUCTURED CONTENT
}

\author{
Sustentabilidade no setor automotivo: análise de conteúdo estruturado
}

\author{
Caroline Rodrigues Vaz, Alvaro Guillermo Rojas Lezana, \\ Mauricio Uriona Maldonado \\ Federal University of Santa Catarina, Brasil
}

Email: karollrvaz@gmail.com, alvaro.lezana@ufsc.br,m.uriona@ufsc.br

\begin{abstract}
This study aimed to carry out an analysis of the scientific production on the sustainable innovation theme in the automotive sector in the last 10 years. The research was classified as literature, descriptive and exploratory. The process presented 31 articles aligned with the research topic in the Scopus database. The bibliometric analysis identified the most relevant articles, authors, keywords, countries, research center and periodicals that published about the subject from 2004 to 2016 in the Production Engineering domain. We concluded, through the systemic analysis, that the automotive sector is well structured on the issue of sustainability and process innovation. The innovations that this sector performs in its processes are incremental, because they are less risky, lower cost and less complex operations. However, some authors explain that radical innovations are needed in order to fit the prevailing environmental standards. The selected studies show that environmental practices employed in the automotive sector are: the minimization of greenhouse gas emissions, life-cycle assessment, cleaner production, reverse logistics and eco-innovation. Thus, it displays the need for practical research studies in automotive companies about the environmental practices employed and how these practices impact innovation.
\end{abstract}

Keywords: Innovation. Sustainability. Automotive industry.

Recebido em: 17/02/2017

Aceito em: 01/06/2017 


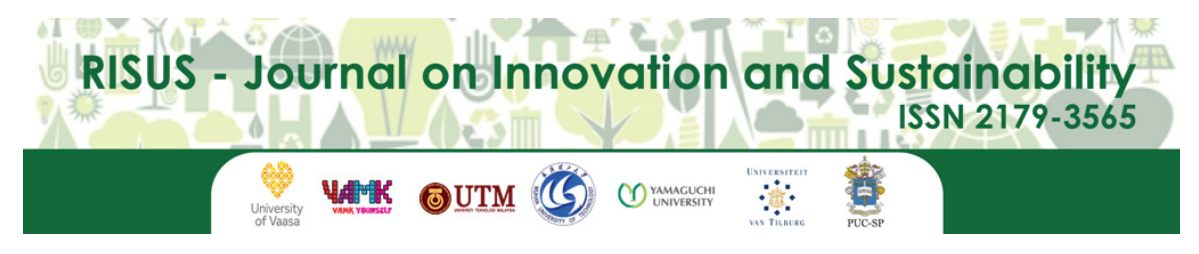

RISUS - Journal on Innovation and Sustainability volume 8 , número 2 - 2017

ISSN: $2179-3565$

Editor Científico: Arnoldo José de Hoyos Guevara Editora Assistente: Lívia Lopes Aguiar

Avaliação: Melhores práticas editoriais da ANPAD

\title{
SUSTAINABILITY IN THE AUTOMOTIVE SECTOR: AN ANALYSIS OF STRUCTURED CONTENT
}

\author{
Sustentabilidade no setor automotivo: análise de conteúdo estruturado
}

\section{Caroline Rodrigues Vaz, Alvaro Guillermo Rojas Lezana, Mauricio Uriona Maldonado Federal University of Santa Catarina, Brasil Email:karollrvaz@gmail.com, alvaro.lezana@ufsc.br,m.uriona@ufsc.br}

\begin{abstract}
Resumo. Este estudo teve como objetivo realizar uma análise da produção científica sobre o tema da inovação sustentável no setor automotivo nos últimos 10 anos. A pesquisa foi classificada como literatura, descritiva e exploratória. O processo apresentou 31 artigos alinhados com o tópico de pesquisa na base de dados Scopus. A análise bibliométrica identificou os artigos mais relevantes, autores, palavras-chave, países, centro de pesquisa e periódicos que publicaram sobre o tema de 2004 a 2016 no setor da Engenharia de Produção. Concluímos, através da análise sistêmica, que o setor automotivo está bem estruturado na questão da sustentabilidade e da inovação de processos. As inovações que este setor realiza em seus processos são incrementais, pois são operações menos arriscadas, de menor custo e menos complexas. No entanto, alguns autores explicam que são necessárias inovações radicais para se adequarem às normas ambientais prevalecentes. Os estudos selecionados mostram que as práticas ambientais utilizadas no setor automotivobasicamente são: a minimização das emissões de gases de efeito estufa, a avaliação do ciclo de vida, a produção mais limpa, a logística reversa e a eco-inovação. Desta forma, evidencia a necessidade de pesquisas práticas em empresas automotivas sobre as práticas ambientais empregadas e sobre como essas práticas impactam a inovação.
\end{abstract}

Palavras-chave: Inovação. Sustentabilidade. Indústria automobilística.

Recebido em: 17/02/2017

Aceito em: 01/06/2017 


\section{INTRODUCTION}

The automotive sector is considered one of the most important for a country's economy and trade - it shapes the industry, the cities, communal and individual life, ever since Henry Ford was able to produce it on a large scale and the banks created specific credit lines to finance the acquisition of the asset. The strength of the automotive sector leverages other sectors of the economy. This segment is the second largest market in the steel industry, consuming approximately $15 \%$ of total production of this material, second only to the construction sector. Other major businesses relating to the automotive industry are the aluminum sector $(5 \%)$, petrochemicals (especially plastics, 7\%) and glass (Itacarambi, 2012).

The automotive industry is relevant in terms of its impact on the economy as well as on technology. As stated by Humphrey and Memedovic (2003), the automotive sector is global and is characterized as a capital-intensive industry with vertical integration and economies of scale (Schulze, MacDuffie \& Taube, 2015). It has been responsible for the development of technological innovation and management, and the original major change on the industrial production processes (Casotti \& Goldenstein, 2008; Barros, Castro \& Vaz, 2014).

Since the mid 80 's, the automotive industry is going through a transition, in which domestic industries are adapting to an integrated global market (Sturgeon, Biesebroeck \& Gereffi, 2008). According to the authors, this integration took place mainly in the buyersupplier relationship, especially among automakers and their suppliers. In the early twentyfirst century, the automotive industry, which had already achieved a level of maturity and high structure, has to be pressed by globalization, government regulations - concerning energy consumption, emissions and safety - and technological advances in electronics, communication and design (Schulze, MacDuffie \& Taube, 2015).

Thus, the auto industry becomes one of the most harmful to man and to the environment. It impacted the environment for the following reasons: i) cars are responsible for most emissions of greenhouse gases in cities; ii) lethality: traffic jams; iii) economic loss: Traffic jams interfere with mobility and proper performance of the economy, as people spend increasingly more time commuting; iv) the area for agriculture is decreased; v) mobility issues; vi) fatalities and accidents; vii) lack of action in terms of the disposal of vehicles and vehicle parts, among others.

However, in the world economy, the automotive industry generates more than $\$ 2.5$ trillion in revenue per year and corresponds, in general, to roughly $10 \%$ of the Gross Domestic Product (GDP) of developed countries (Casotti and Goldenstein, 2008). According to annual data from the National Association of Vehicle Manufacturers (Anfavea, 2014), in 2008, China surpassed the United States in the production of auto vehicles. During this period, China produced 9,299,000 units against 8,695,000 units in the North American country. In 2012, China produced 19.272 million units and the United States ranked second with 10.329 million units, followed by Japan, Germany and South Korea, with 9,943, 5,649 and 4,558,000 units, respectively. Brazil was in 7 th place with a total of 3.403 million units. 
According to the Ministry of Development, Industry and Foreign Trade (MDIC), the Brazilian automotive sector accounted for approximately $23 \%$ of the industrial GDP and $5 \%$ of the GDP in 2014 (MDIC, 2016). In 2006, the Brazilian automotive industry had 24 manufacturers and more than 500 auto parts companies, with productive capacity of 3.5 million vehicles per year (ANFAVEA, 2006). In 2008, the number of automakers had already escalated to 27, with 49 industrial plants between the manufacturers of auto vehicles, agricultural machines, engines and components. In the world rankings of 2014, Brazil emerged as the 8th largest producer of vehicles, behind China, the United States, Japan, Germany, South Korea, India and Mexico, and as the 4th in terms of domestic vehicles, behind China, USA and Japan (MDIC, 2015).

In consequence of this large production, many studies have sought to reflect upon the impact of cars on civilization and possible solutions and alternatives to the problems that it raises. One of the alternatives is the verification and implementation of sustainable practices and the use of clean technologies in the automotive industries' production processes, aiming at some innovative programs and actions to address the dilemmas of sustainable development. The 2012 Uniethos study analyzed the social responsibility and sustainability practices of the seven largest automakers in the world, some examples from the study are as follows:

i) In the European Union, there is a Competitive Automotive Regulatory System for the 21st Century (CARS 21), a link between the automotive industry, national governments, environmentalists, unions, suppliers, customers, the oil industry, the European Parliament and European Commission with the aim of enhancing the overall competitiveness of the industry, as well as maintaining jobs and making progress in safety and environmental performance at an affordable price to the consumer. In the 2012 report, there are recommendations for the industry to reach a new level in 2020: funding for new technology research aimed at energy efficiency and reducing GHG emissions; managing the sector's costs through regulations; negotiating to reach regulatory frameworks; promoting convergences and procedures in order to obtain approval for a world car model. This will allow any car produced in the world to be sold in any country.

ii) In the US, Ford, GM, Chrysler, Honda and Toyota began working together in 2005 through the Automotive Industry Action Group Initiative (Aiagi) to explore a cooperative approach to industry, seeking to promote decent working conditions in the supply chain, with suppliers working in various locations around the world, including Brazil.

iii) In China, GM signed an agreement with the Shanghai Automotive Industry Corporation (SAIC) for the joint development of new engines as well as a memorandum of understanding to explore cooperation in new energy vehicles (e.g. electric cars). Other agreements incorporate the strategy to introduce twelve new and more efficient engines by 2015. GM also has a memorandum of understanding with the Tianjin Eco-City to solve mobility problems. The Tianjin Eco-City is a $30-\mathrm{km}^{2}$ project being built near the city of Tianjin, China, intended to be a showcase of new technologies and a model for sustainable urban development of cities. GM has delivered the Volt model, an electric car that conserves energy. The battery feeds for $80 \mathrm{~km}$ and when it is discharged, a motor in the generator produces enough electricity for over $490 \mathrm{~km}$. 
The study found that the same automakers that are operating in Brazil have advanced projects and actions in other countries, facing the challenges of sustainability. However, according to the Uniethos survey, CSR practices and sustainability at the national level are well below those applied in Europe, the US and Asia. Therefore, this research aims to conduct an analysis of the scientific production on the sustainable innovation theme in the automotive sector in the last 10 years.

The article is divided into five sections, the first of which comprehends this introduction. The second presents the theoretical framework of innovation and sustainability issues. The third establishes the methodology used in this research. The fourth section reports on the results and their discussion. Finally, we present conclusions and future recommendations.

\section{INNOVATION AND SUSTAINABILITY}

The sustainability of the business can be understood in a conventional way, i.e. as the ability to generate funds to remunerate the factors of production, replenish the used assets and invest to continue competing. In such a way, there is nothing new about innovations being the product of technology and service and process being the management and business model. These are longstanding understandings and stem from the idea that an organization must have continuity that extends indefinitely, as suggested by their social contracts. But if the business sustainability is understood as an effective contribution to sustainable development, then the innovations now present additional assessment criteria in relation to the conventional. There is no other reason for this issue to be a part of the core of the concept of sustainable development. Even the origins of the sustainable development movement were severely criticized for certain successful innovations, as did Rachel Carson in regards to the DDT (Carson, 2002).

According to this movement's concepts of sustainability, innovation should generate economic results and, simultaneously, a social and positive environment, which is not easily attained given the uncertainties that innovations bring about, especially when novelty is extreme or high in relation to the state of the art. The economic effects are relatively easy to predict, for there is an enormous quantity of tools developed for that purpose and innovative companies that know how to use them. Social and environmental effects are more difficult to assess beforehand, as they encompass more variables, uncertainties and interactions. So, the most frequently observed is the continuity of the conventional understanding accompanied by a discourse that incorporates the theme of sustainable development which boils down to merely good intentions, if not a means to appropriate an idea that is gaining momentum with the population and opinion leaders. Sustainable development demands a combination of technical and social changes, since these are all closely related (Geels \& Schot, 2008).

Innovation, according to the Oslo Manual, is the implementation of a new or significantly improved product, good or service, or a process, or a new marketing method, or a new organizational method in business practices, in local organizations' work or external relations (OECD, 1997, p. 55). Based on this definition, Kemp and Pearson (2008) defined "ecoinnovation" as "the production, assimilation or exploration of a product, production process, service or method of management or business that is new to the organization (developing or adopting it) which results, throughout their life cycle, in the reduction of environmental risk, pollution and other negative impacts of the use of resources, including energy, in comparison to relevant alternatives" (Kemp \& Pearson, 2008, p. 7). Due to the negative impacts that usually accompany innovations, such as pollutant emissions and depletion of natural resources, the definition emphasizes the reduction of problems, assuming that the economic benefits will be somehow perceived. 
Note that "eco-innovation" refers to "eco-efficiency", procedures resulting from the intersection of two dimensions of sustainability, namely the economic and social. Eco-efficiency is a practice that rests between the economic and environmental pillars. This entails developing goods and services that satisfy human needs at competitive prices and that can progressively reduce environmental impacts to a next level supportable by the Earth (Elkington, 2001, p. 82). Eco-efficient innovations, for example, reduce the amount of materials and energy per unit produced, eliminate toxic substances and increase the life of the product. However, they can generate unemployment, extinguishing skills, harming communities or segments of society, and other social problems. Therefore, the social dimension must be accounted for in eco-efficient innovation so that is also sustainable innovation.

In a similar operation to the aforementioned authors, "sustainable innovation" is the introduction (production, assimilation or exploration) of products, production processes, management and business methods, new or significantly improved in the organization, bringing about economic, social and environmental improvements in comparison to relevant alternatives. Note that this is not only to reduce negative impacts, but to also advance in net benefits. The stressed condition, "compared to relevant alternatives," is essential to the concept of sustainable innovation because the expected benefits should be significant or not negligible in the three dimensions of sustainability. As Barbieri (2007) states, the evaluation of the environmental consequences should be part of the innovation processes and not just the economic evaluation. It is usual to find in the literature on innovation management that the expectation of negative economic results or lower than expected stops or redirects a specific innovation process. Interrupting or redirecting a project should occur in consequence of results that are socially and environmentally negative or lower than expected.

\section{METHODOLOGY}

\section{RESEARCH CLASSIFICATION}

This research is characterized as theoretical in nature regarding the topic discussed. As for its technical procedures, it corresponds to a bibliographic study, as we address data and verifications stemming directly from work already done on the researched subject. The perspective's objectives are classified as exploratory and descriptive, since they seek specific information and characteristics of what is being studied (GIL, 2007).

\section{RESEARCH PROCEDURES}

A structured review of the literature, by bibliometric analysis was performed according to the ProKnow-C (Knowledge Process Development - Constructivist) method proposed by Ensslin et al. (2010).

The ProKnow-C intervention method proposed by Ensslin et al. (2010) for selecting a bibliographic portfolio consists of a four step process: i) Selection of database of raw articles, which, in turn, comprehends: selecting keywords, selecting databases, searching for articles and verifying the adherence of keywords; ii) Filtering the raw articles database, which entails filtering the raw articles of the database by redundancy and filtering the raw articles of the database that are not repeated by the alignment with the title; iii) Filtering the article database, pertaining to: determining the scientific recognition of articles, author identification; iv) Filtering by alignment to the full article, concerning the full text of the articles. 
The bibliometric analysis is a technique for mapping the main authors, journals and keywords on a particular theme. Uriona Maldonado, Silva Santos and Santos (2010) argue that these techniques are tools that rely on a scientifically recognized methodological theoretical basis, which allows the use of statistical and mathematical methods to map information from bibliographic records of the documents stored in the data in databases.

In addition, the bibliometric analysis definition by Ensslin et al. (2010, p1) is as follows:

It is the process of quantitative divulgation of statistic data of a define set of articles (bibliographic portfolio) for the information management and scientific knowledge of certain subject, conducted through document counting.

For the bibliometric analysis items contained in the bibliographic portfolio and references are used to determine the degree of relevance of journals, the degree of scientific recognition of items, the degree of relevance of authors, institutions and countries and the most used keywords.

Initially, we defined keywords on Innovation, Sustainability and Automotive Industry in order to select articles in the CAPES (Coordination for the Improvement of Higher Education Personnel) database. We selected Scopus as our consulting database, since it is multidisciplinary and indexes only the most cited journals in their respective fields. It indexes over 15,000 periodicals, approximately 265 million web pages, 18 million patents, among other documents.

The EndNote X7 software (ENDNOTE, 2014) was used to manage and treat the references collected. The Endnote software is a reference manager created by Thomson Scientific, which works in integration with Web of Science. It facilitates research work and the writing of scientific work, gathering references from online databases, importing their metadata and grouping them in different ways.

\section{RESULTS AND DISCUSSION}

The literature review, to the researcher, is the first step in developing a work and building knowledge in a given context. It also allows an introductory vision in the development of a research project and resumes the accumulated scientific knowledge on the subject (Afonso et al., 2012). It also makes the researcher more familiar with the subject, permitting new constructs and definitions.

Creswell (2010) corroborates, remarking that the literature review fulfills several purposes, one of which is to share with the reader the results of other studies that are directly related to what is being done and/or researched. This measure enables greater dialogue around the study, contributing to the literature, filling gaps and extending prior studies.

Lacerda (2010) states that with the evolution of information systems, the use of databases (indexed systems) facilitates searches for references and the construction of theoretical platforms for future research. In the present paper, the results and discussions are presented in three subsections: i) creation of bibliographic portfolio; ii) bibliometric analysis and iii) systemic analysis. 


\section{CREATION OF BIBLIOGRAPHIC PORTFOLIO}

We conducted a search through CAPES database - Scopus, in August 2016, using a combination of the keywords "Sustainabilit *", "Innovat *" and "Automotive", which resulted in $91 \mathrm{raw}$ articles related to the searched topics in the last 10 years. These were divided by areas of research: $22 \%$ stemmed from engineering, $20 \%$ from business and management, $12 \%$ from social management and 9\% from the energy area. However, this work focused on the Engineering area, which comprises 50 raw articles, as shown in Figure 1.

Figure 1 - Areas of the articles found in Scopus database

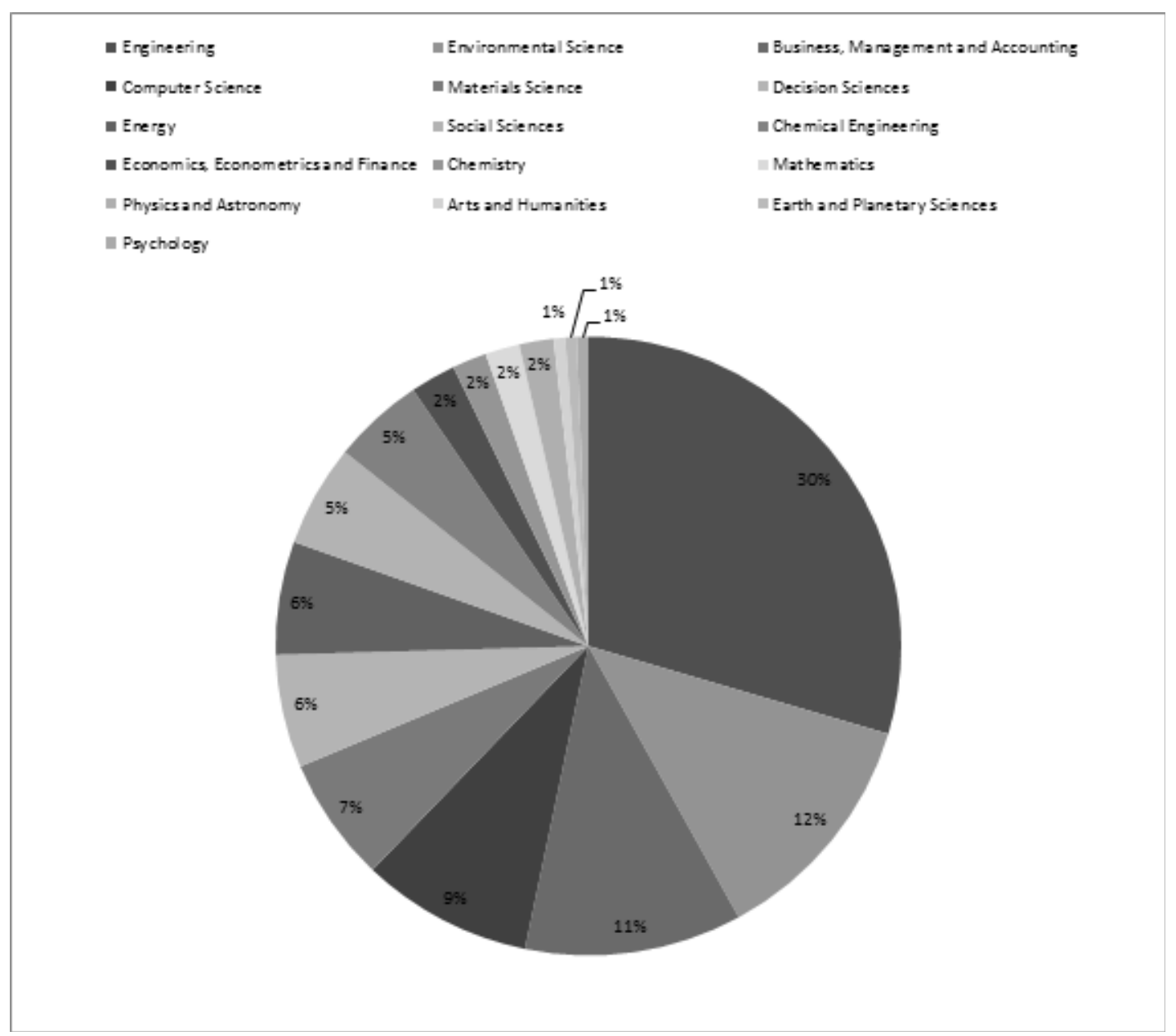

Source: Research data, 2016. 
In order to create the bibliographic portfolio, some aspects are considered to filter the articles to be studied, namely: (i) the presence of repeated/duplicated articles; (ii) the alignment of the articles' titles with the theme; (iii) scientific recognition of the articles; (iv) alignment of articles' abstract with the theme; and (v) availability of full articles in the database. Table 1 presents the filtering results applied to the 91 raw articles found in the database.

Table 1. Filters to select articles for the Bibliographic Portfolio

\begin{tabular}{|l|c|}
\hline \multicolumn{1}{|c|}{ Filter } & \# of Articles \\
\hline Total number of articles in the database & 91 \\
\hline Duplicated articles & 01 \\
\hline Articles from Engineering area & 50 \\
\hline Articles only from Journals & 43 \\
\hline Aligned title & 41 \\
\hline Aligned abstract & 26 \\
\hline Full articles available for free & 17 \\
\hline Exploratory Search on Google Scholar & 14 \\
\hline Bibliographic portfolio & $\mathbf{3 1}$ \\
\hline
\end{tabular}

Source: Results of data collection.

Thus, Table 1 presents the 31 articles aligned with the theme of "Sustainability AND Innovation AND Automotive Sector", which will be subjected to bibliometric and content analyses. 


\section{Table 1. List of articles aligned with the theme}

\begin{tabular}{|c|c|c|}
\hline Author & Year & Title \\
\hline van den Hoed; R. and Vergragt; P. J. & 2004 & $\begin{array}{l}\text { Institutional change in the automotive industry: Or how fuel cell } \\
\text { technology is being institutionalized }\end{array}$ \\
\hline Jobson; E. & 2004 & Future challenges in automotive emission control \\
\hline Williams; A. & 2006 & $\begin{array}{l}\text { Product-service systems in the automotive industry: The case of micro- } \\
\text { factory retailing }\end{array}$ \\
\hline Williams; A. & 2007 & $\begin{array}{l}\text { Product service systems in the automobile industry: contribution to } \\
\text { system innovation? }\end{array}$ \\
\hline Van den Hoed; R. & 2007 & $\begin{array}{l}\text { Sources of radical technological innovation: the emergence of fuel cell } \\
\text { technology in the automotive industry }\end{array}$ \\
\hline Ploss; R;; Mueller; A. and Leteinturier; P. & 2008 & Solving automotive challenges with electronics \\
\hline De Vries; R.P. & 2008 & IC innovations in automotive \\
\hline Resta; B.; Gaiardelli; P. and Pezzotta; G. & 2009 & $\begin{array}{l}\text { Sustainability in the auto repair industry: A life cycle assessment } \\
\text { application }\end{array}$ \\
\hline Elmquist; M. and Segrestin; B. & 2009 & $\begin{array}{l}\text { Sustainable development through innovative design: Lessons from the } \\
\text { KCP method experimented with an automotive firm }\end{array}$ \\
\hline Bull; K.; Hull; N. and Peck; D. & 2009 & $\begin{array}{l}\text { Broadening industry perspectives of vehicle telematics application } \\
\text { through virtual leaming environments: EADIS: European automotive } \\
\text { digital interaction studio }\end{array}$ \\
\hline Ros; J.; Nagelhout; D. and Montfoort; J. & 2009 & $\begin{array}{l}\text { New environmental policy for system innovation: Casus alternatives } \\
\text { for fossil motor fuels }\end{array}$ \\
\hline Cruceru; G. and Micuda; D. & 2010 & $\begin{array}{l}\text { The european auto market under the impact of the financial crisis: } \\
\text { Lessons to be leamed }\end{array}$ \\
\hline Ceschin; F. and Vezzoli; C. & 2010 & $\begin{array}{l}\text { The role of public policy in stimulating radical environmental impact } \\
\text { reduction in the automotive sector: The need to focus on product- } \\
\text { service system innovation }\end{array}$ \\
\hline $\begin{array}{l}\text { Bonilla; S. H.; Almeida; C. M. V. B.; Giannetti; B. F. and } \\
\text { Huisingh; D. }\end{array}$ & 2010 & $\begin{array}{l}\text { The roles of cleaner production in the sustainable development of } \\
\text { modem societies: an introduction to this special issue }\end{array}$ \\
\hline Avadikyan; A. and Llerena; $P$. & 2010 & A real options reasoning approach to hybrid vehicle investments \\
\hline Brookes; $\mathrm{K}$. & 2011 & Unique values win PM design awards \\
\hline Cortez; M. A. A. and Cudia; C. P. & 2011 & $\begin{array}{l}\text { The virtuous cycles between environmental innovations and financial } \\
\text { performance: Case study of japanese automotive and electronics }\end{array}$ \\
\hline Millet; D.; Yvars; P. A. and Tonnelier; P. & 2012 & $\begin{array}{l}\text { A method for identifying the worst recycling case: Application on a } \\
\text { range of vehicles in the automotive sector }\end{array}$ \\
\hline Wang; Y.; Zhang; H. and Sun; Z. & 2013 & $\begin{array}{l}\text { Optimal control of the transient emissions and the fuel efficiency of a } \\
\text { diesel hybrid electric vehicle }\end{array}$ \\
\hline Holtskog; H. and Ringen; G. & 2013 & Opportunities in the wake of crisis \\
\hline Bracke; S.; Michalski; J.; Inoue; M. and Yamada; T. & 2013 & $\begin{array}{l}\text { CDMF-RELSUS concept: Reliable products are sustainable products - } \\
\text { Influences on product design; manufacturing and use phase }\end{array}$ \\
\hline Wells; P. & 2013 & $\begin{array}{l}\text { Sustainable business models and the automotive industry: A } \\
\text { commentary }\end{array}$ \\
\hline Intarakumnerd; P. and Chaoroenporm; P. & 2013 & $\begin{array}{l}\text { The roles of intermediaries and the development of their capabilities in } \\
\text { sectoral innovation systems: A case study of Thailand }\end{array}$ \\
\hline Vieira do Nascimento; D. M. & 2014 & $\begin{array}{l}\text { The Brazilian experience of flex-fuel vehicles technology: Towards } \\
\text { low carbon mobility }\end{array}$ \\
\hline Pusavec; F. and Kenda; J. & 2014 & $\begin{array}{l}\text { The transition to a clean; dry; and energy efficient polishing process: } \\
\text { An innovative upgrade of abrasive flow machining for simultaneous } \\
\text { generation of micro-geometry and polishing in the tooling industry }\end{array}$ \\
\hline Penza; M. & 2014 & $\begin{array}{l}\text { COST Action TD1105: New sensing technologies for environmental } \\
\text { sustainability in smart cities }\end{array}$ \\
\hline Bracke; S.; Inoue; M.; Ulutas; B. and Yamada; T. & 2014 & $\begin{array}{l}\text { CDMF-RELSUS concept: Reliable and Sustainable products - } \\
\text { Influences on design; manufacturing; layout integration and use phase }\end{array}$ \\
\hline Vinodh; S.; Kamala; V. and Jayakrishna; K. & 2014 & $\begin{array}{l}\text { Integration of ECQFD; TRIZ; and AHP for innovative and sustainable } \\
\text { product development }\end{array}$ \\
\hline Okushima; M. & 2015 & $\begin{array}{l}\text { Simulating social influences on sustainable mobility shifts for } \\
\text { heterogeneous agents }\end{array}$ \\
\hline Chou; C. W.; Liao; W. C.; Wu; S. and Wee; H. M. & 2015 & $\begin{array}{l}\text { The role of technical innovation and sustainability on energy } \\
\text { consumption: A case study on the Taiwanese automobile industry }\end{array}$ \\
\hline Amatucci; M. & 2015 & $\begin{array}{l}\text { The world that chose the machine: An evolutionary view of the } \\
\text { technological race in the history of the automobile }\end{array}$ \\
\hline
\end{tabular}

Source: Authors, 2016 survey data. 


\section{BIBLIOMETRIC ANALYSIS}

Figure 2 shows a relation of the 31 articles by periodicity of publication. Hence, we can identify that the first articles published on the theme of this research took place on 2004, namely:

i) Future challenges in automotive emission control, by Jobson, E.: The article deals with the global perspective on emissions by automotive vehicles, in future scenarios of energy production and consumption, the growing population and trade. Addressing, thusly, the main technologic and scientific challenges to NOx reduction.

ii) Institutional change in the automotive industry: Or how fuel cell technology is being institutionalized, by Van den Hoed, R. and Vergragt, P.J.: The article addresses the need for change in the automotive industries, in order to attain sustainability, in relation to fuel cells. It tries to answer the following questions: Why is the industry adopting such technology? How is fuel cell technology in regards to the process of becoming institutionalized?

Figure 2 - Periodicity of publications

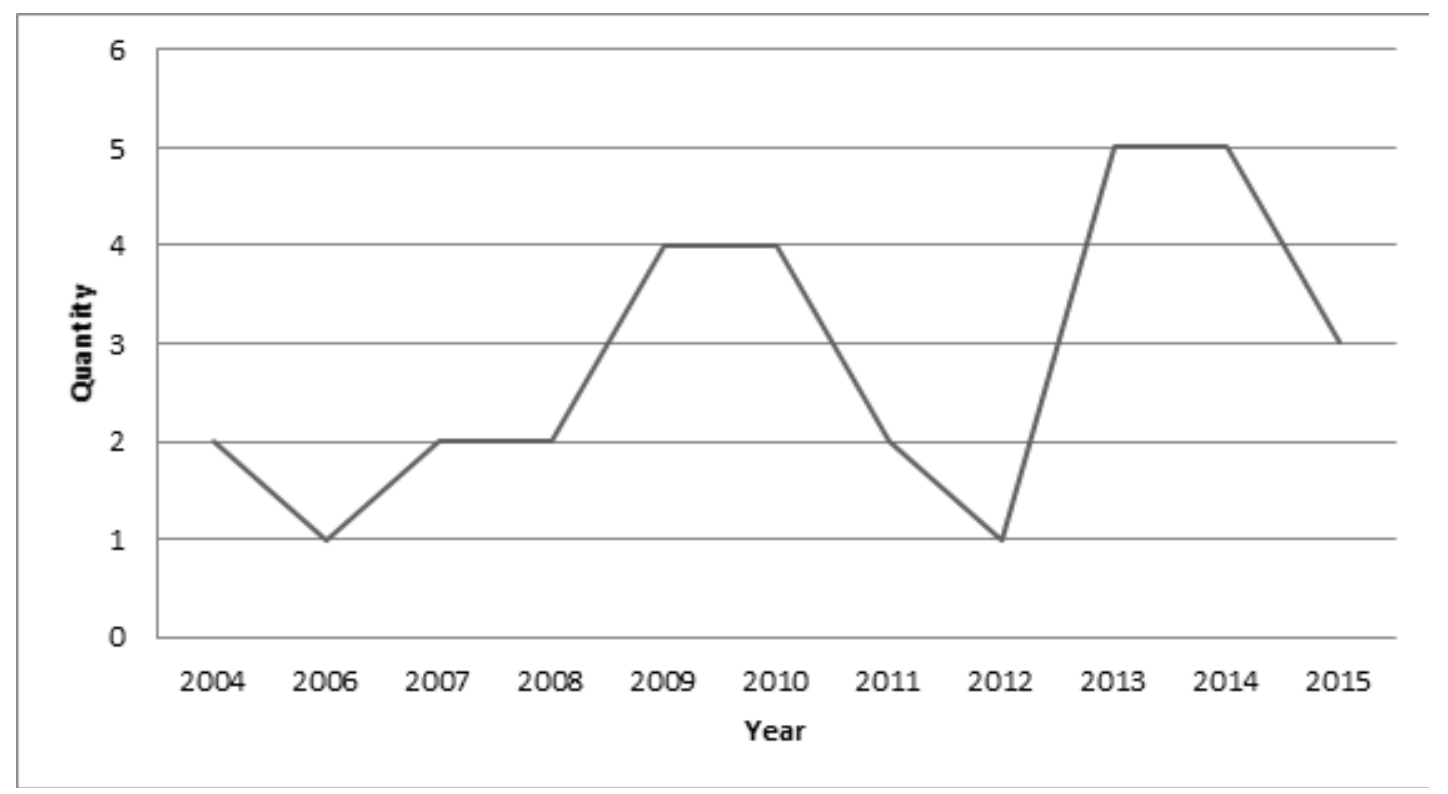


Regarding the most relevant authors, we identified 61 authors and co-authors in the 31 articles found in the database. The most prolific were Yamada T., Williams A., Van den Hoed R., Inoue M. and Bracke S., with two articles each, as shown in Figure 3.

Figure 3 - Authors Relation

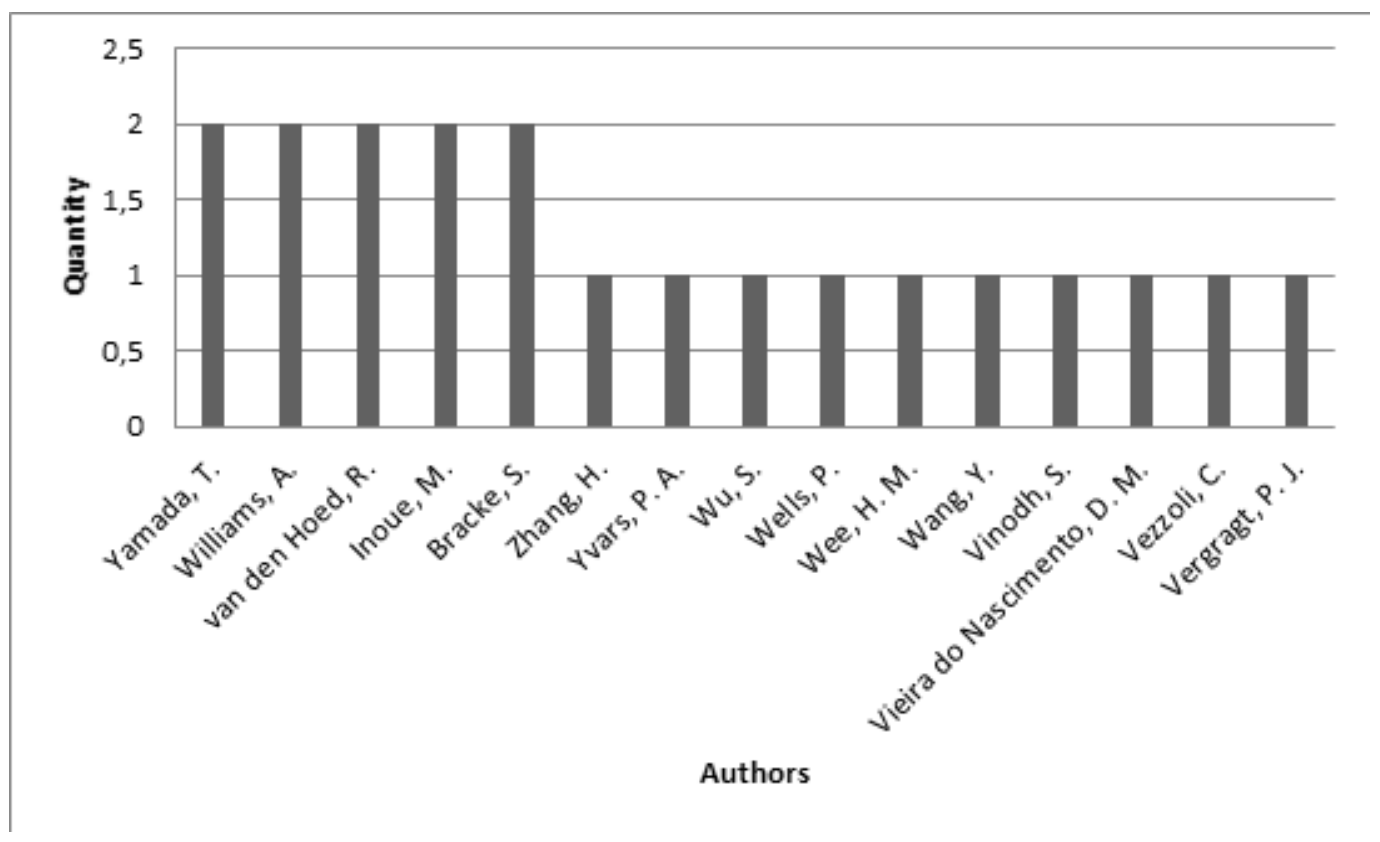

Source: Research data, 2016.

Pertaining to periodics, we identified 25 Journals in which the authors published their articles. The Journal of Cleaner Production, focusing on environmental matters, stood out with five articles, with one publication in 2006, two in 2007, one in 2010 and one in 2014, respectively, which can be visualized in Table 1 . 
Table 1 - Periodic Relationship

\begin{tabular}{|l|r|}
\hline Periodic & Quantity of articles \\
\hline Journal of Cleaner Production & 5 \\
\hline Intermational Journal of Automotive Technology and Management & 3 \\
\hline Transportation & 1 \\
\hline Topics in Catalysis & 1 \\
\hline Technological Forecasting and Social Change & 1 \\
\hline Resources, Conservation and Recycling & 1 \\
\hline Proceedings of the Institution of Mechanical Engineers, Part D: Journal of Automobile Engineering & 1 \\
\hline Procedia CIRP & 1 \\
\hline Metal Powder Report & 1 \\
\hline Intemational Joumal of Sustainable Manufacturing & 1 \\
\hline Intemational Journal of Product Lifecycle Management & 1 \\
\hline Intermational Conference on Risk Management, Assessment and Mitigation, RIMA '10 & 1 \\
\hline IIMB Management Review & 1 \\
\hline Greener Management International & 1 \\
\hline Energies & 1 \\
\hline Asian Joumal of Technology Innovation & 1 \\
\hline Applied Mathematical Modelling & 1 \\
\hline Applied Energy & 1 \\
\hline Academy of Accounting and Financial Studies Joumal & 1 \\
\hline 46th CIRP Conference on Manufacturing Systems, CIRP CMS 2013 & 1 \\
\hline 20th Intermational Conference on Urban Transport and the Environment, UT 2014 & 1 \\
\hline 2008 Intemational Symposium on VLSI Technology, Systems and Applications, VLSITSA & 1 \\
\hline 2008 9th Intemational Conference on SolidState and IntegratedCircuit Technology, ICSICT 2008 & 1 \\
\hline 16th World Congress on Intelligent Transport Systems and Services, ITS 2009 & 1 \\
\hline 13th IEEE SENSORS Conference, SENSORS 2014 & \\
\hline
\end{tabular}

Source: Research data, 2016.

Our research concluded that the country that develops the most research on the theme are the United States, with seven published articles. Brazil has two published articles. 
Figure 4 - List of countries that developed articles

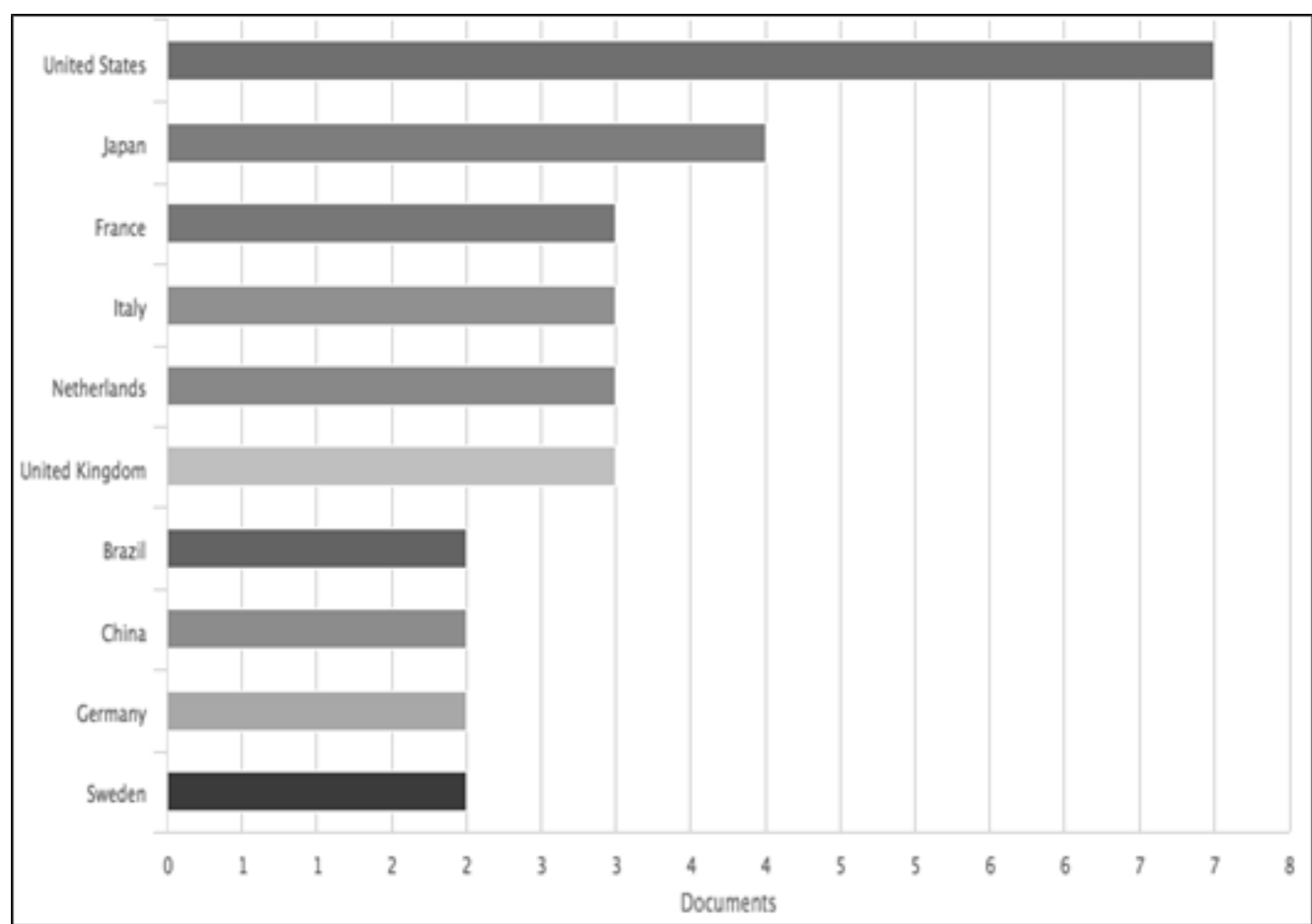

Source: Research data, 2016.

Figure 5 shows the list of education and research institutions that developed the most work on the theme of sustainability and innovation in the automotive sector, namely Cardiff University ( 3 articles), followed by Delf University of Technology ( 2 articles).

Figura 5 - Relação das instituições de ensino que desenvolveram os artigos

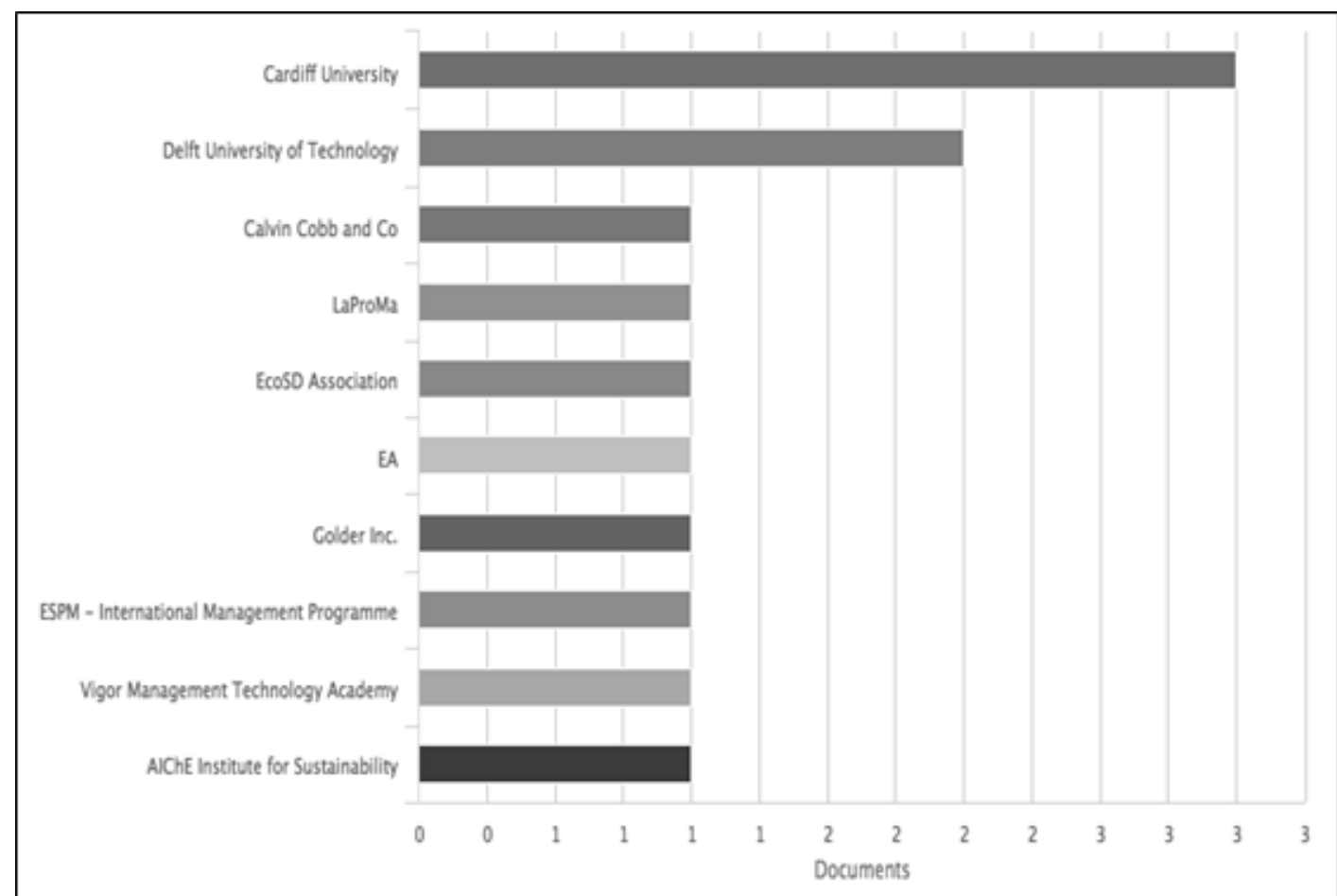

Source: Research data, 2016. 
Figure 6 displays the list of keywords utilized by the 31 authors. There were 266 words and the most representative of these are highlighted bellow. We can observe that the words "automotive industry", "innovation", "sustainability" and "sustainable development" are the among the most repeated, which validates the adherence of the keyword used in the selection of the articles in the found articles.

Figure 6 - List of keywords

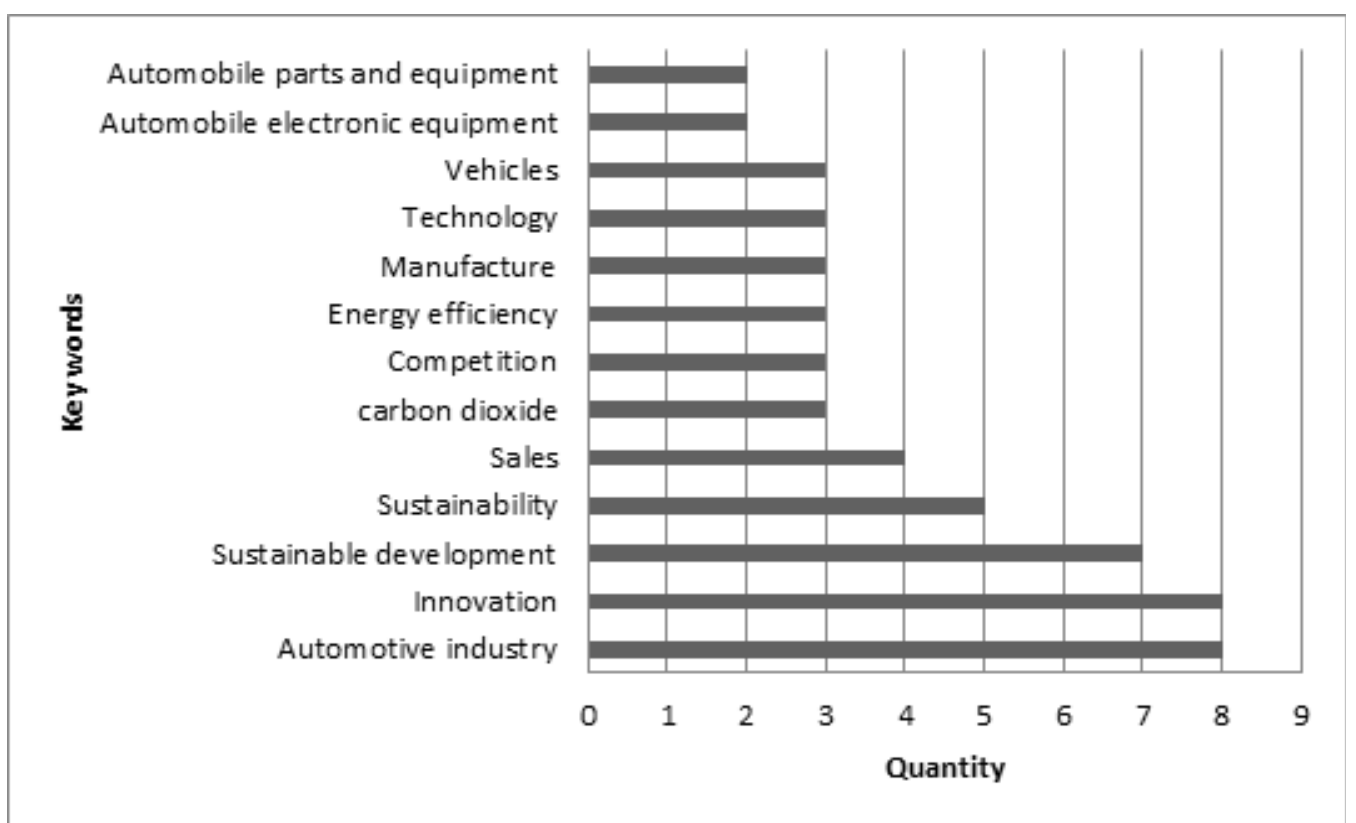

Source: Research data, 2016.

Figure 7 provides evidence of the most relevant words in the articles' titles, since the highlighted words are the most repeated ones and represent the scope of the themes of each article. Note the presence of the terms "Innovation", "Automotive", "Sustainable", "Product" e "Industry".

Figure 7 - Representativeness of the themes in the titles of the articles

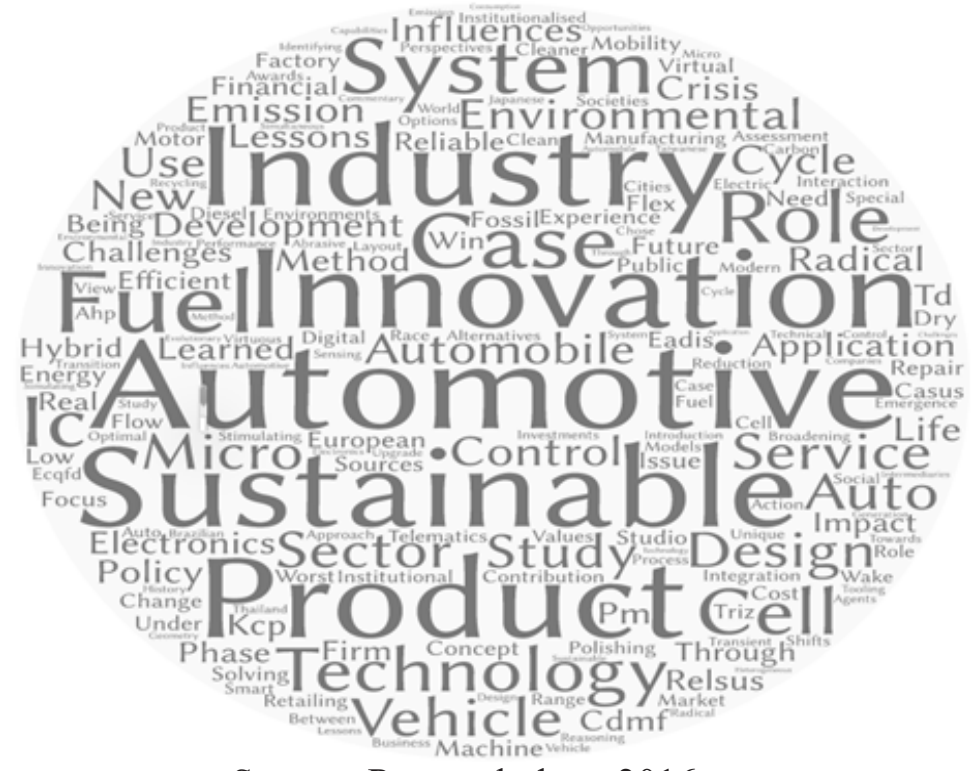

Source: Research data, 2016. 
The next item reports on the articles' content analysis in order to verify how the researchers are addressing the theme and identify the possible gaps in researches on the theme of sustainable innovation in the automotive sector.

\section{CONTENT ANALYSIS}

After the bibliometric analysis, we conducted content analysis on the 31 articles selected from the Scopus database. Some search criteria/queries were established for the analysis, as shown in Table 2.

Table 2 - Content Analysis Criteria

\begin{tabular}{|l|l|}
\hline \multicolumn{1}{|c|}{ Criteria/Queries } & \multicolumn{1}{c|}{ Description } \\
\hline $\begin{array}{l}\text { What is the classification of the article? And its research } \\
\text { method? }\end{array}$ & $\begin{array}{l}\text { The research classification resides in verifying the } \\
\text { methodological orientation, if the article is described } \\
\text { theoretically (as literature review, simulation, among others) or } \\
\text { empirically (as case studies, surveys, among others). }\end{array}$ \\
\hline Which is the geographic delimitation? & $\begin{array}{l}\text { Geographic delimitation is the area or region delimited by } \\
\text { researchers under the ownership of a person or a group, an } \\
\text { organization or an institution, as well as the physical space on } \\
\text { which they wish to conduct research (country, state, region). }\end{array}$ \\
\hline $\begin{array}{l}\text { What is the nomenclature that the authors bring to innovation in } \\
\text { the context of sustainability? }\end{array}$ & $\begin{array}{l}\text { In specialized literature, there are varied nomenclatures about } \\
\text { innovation in relation to sustainability, for instance: eco- } \\
\text { innovation, eco-efficiency, sustainable innovation. }\end{array}$ \\
\hline $\begin{array}{l}\text { Which is the innovation that the researchers bring to the } \\
\text { automotive sector? How does this innovation impacts the issue } \\
\text { of sustainability in the company? }\end{array}$ & $\begin{array}{l}\text { Innovation may be radical (the product/service is integrally } \\
\text { modified, transforming into a new product/service) or } \\
\text { incremental (the product/service is incremented by something } \\
\text { new, but it is not another product/service). }\end{array}$ \\
\hline What are the environmental practices used in the articles? & $\begin{array}{l}\text { The most used environmental practices in companies are ISO } \\
14001, \text { life-cycle assessment, cleaner production, clean } \\
\text { production, industrial ecology, eco-design, eco-innovation, } \\
\text { reverse logistics and environmental logistics. }\end{array}$ \\
\hline
\end{tabular}

Source: Authors.

We verified that of the 31 selected articles, $87 \%$ are of theoretical nature and $13 \%$, empirical, and that the publications were carried out between 2004 and 2015. Figure 8 presents the articles' classification and period of publication for each of them, respectively.

Figure 8 - Articles' classification and publication period

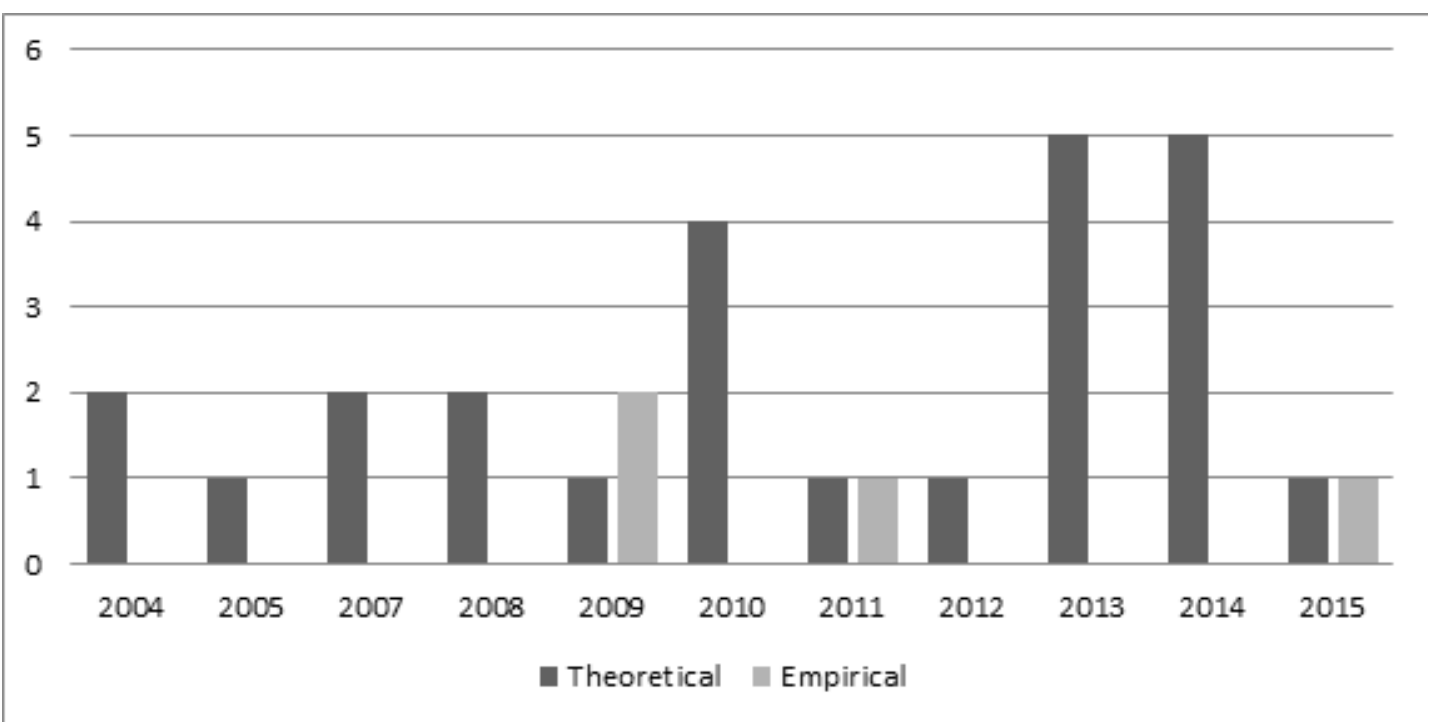

Source: Research data, 2016. 
Figure 9 displays the research methods utilized in the 31 articles. We can assert that $31 \%$ of the articles address practical researches in developed countries, such as the research conducted by Chou et al. (2015) in Taiwanese automotive companies and Jobson (2004), who reports on Great Britain and Europe. 23\% of the works are literature reviews and 23\% multiple case studies, already described in literature, as presented data from the companies Nissan, Ford, Toyota, among others. 15\% were conducted based on legislation and environmental guidelines. Finally, $8 \%$ of the articles were developed on automotive patents, such as the work by Van Den Hoed (2007).

Figure 9 - Research Methods

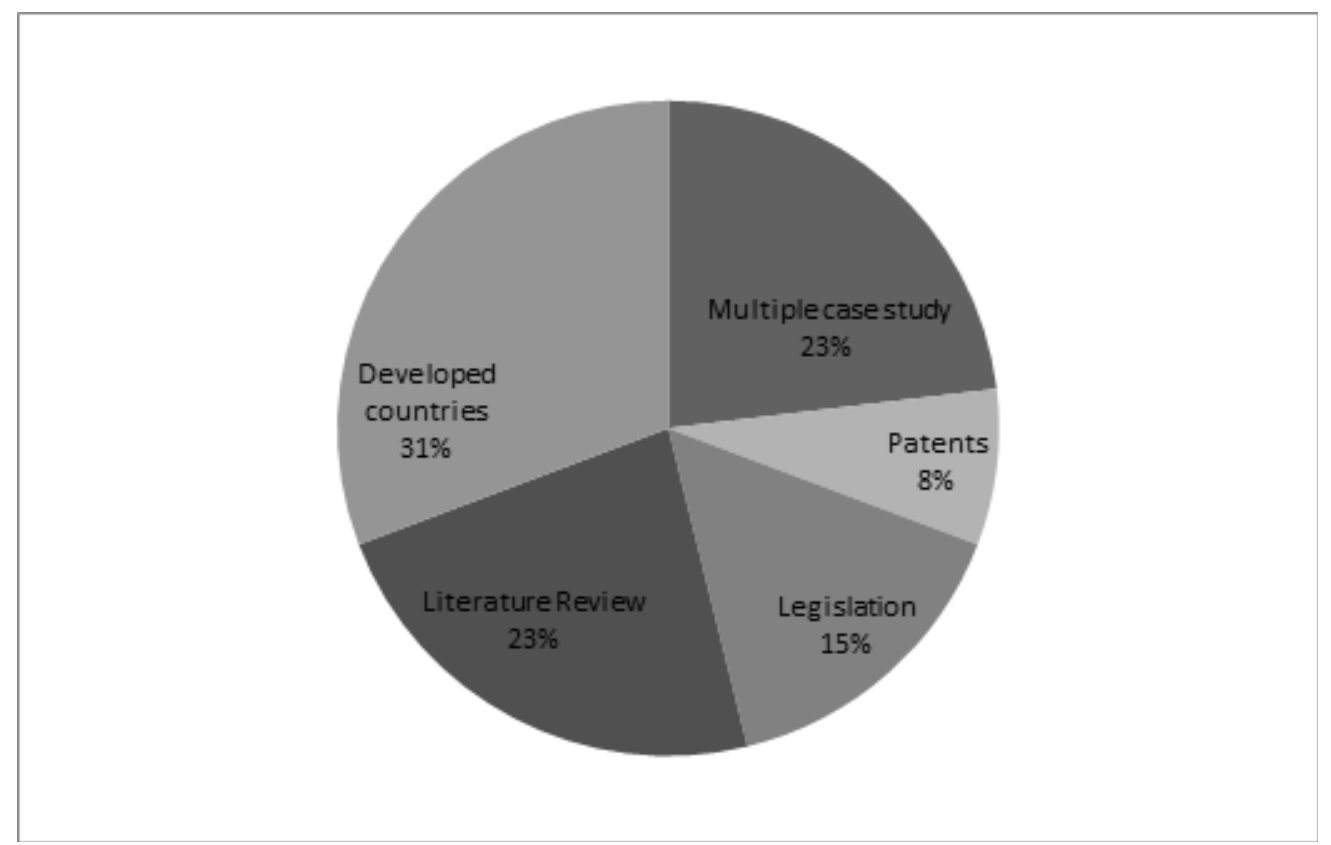

Source: Research data, 2016.

Environmental practices, found in the 31 articles, were related to issues of gas emission in $37 \%$ of the cases, eco-innovation in $27 \%$, life-cycle assessment in $18 \%$, cleaner production in $9 \%$ and reverse logistics in 9\%, as shown in Figure 10.

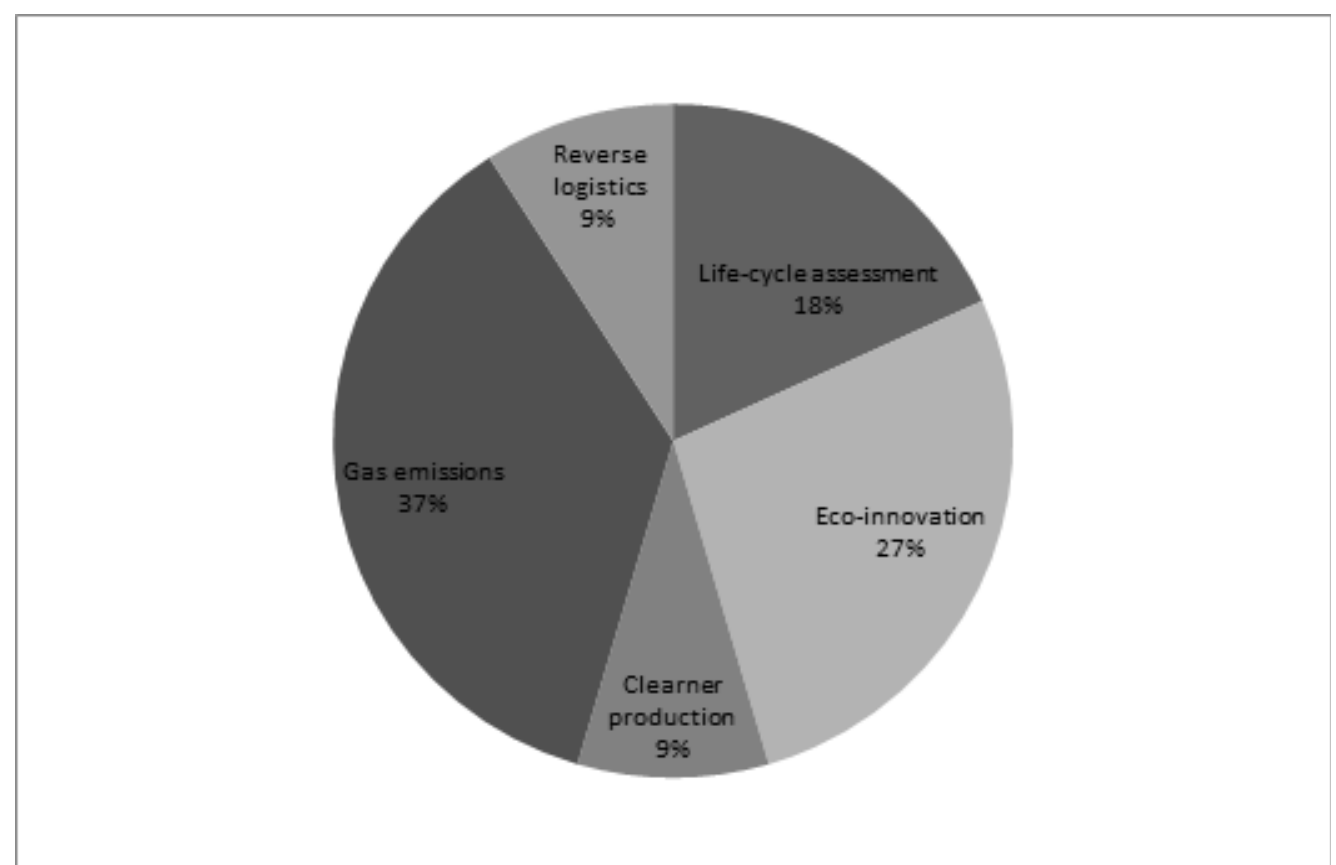


The articles relating to the practice of gas emission, address how to minimize the carbon dioxide and hydrocarbon gases. Car exhaust fumes are approximately $30 \%$ of total atmospheric global emissions and $17 \%$ of $\mathrm{CO} 2$ emissions, one of the main contributors to climate change processes, and brings about varied negative outcomes such as mortality, non-allergic respiratory disease, allergic diseases and symptoms, as well as various forms of cancer (Resta, Gaiardelli \& Pezzotta, 2009).

Van Den Hoed (2007) explains that a central component of the unsustainability of cars today is the internal combustion engine (ICE), associated to the emissions, the use of fossil fuel and noise. The transition to battery electric vehicles (BEV) requires radical and expensive changes in automotive operations and cannot, therefore, be expected. However, in the last few years, significant amount of resources were spent in developing fuel cell vehicles (FCV), in which the fuel cell substitutes the combustion engine.

Resta, Gaiardelli and Pezzotta (2009) show that the applications of life-cycle assessment in automotive industry has focused mainly on technologic innovation of product or fabrication processes. On the other hand, the authors explain that automotive companies have not concentrated their efforts on promoting sustainable actions on service activities although the application of sustainability concepts in this context should represent a new way to reach competitiveness. The authors argue that to reduce the environmental impacts associated to the production processes, car manufacturers have focused their efforts in input use, improving energy efficiency, using renewable energy sources and promoting the efficient use of water, generating outputs, working on waste management and reducing the use of hazardous substances, as well as intelligent mobility solutions (for example, the promotion of green travel plans).

The introduction of reverse logistic solutions, that deal with how products are collected from the end user and returned to a facility, can support a company to comply with the legislation and, at the same time, lead to economical and environmental benefits (Resta, Gaiardelli \& Pezzotta, 2009)

Bonilla et al. (2010) emphasize that the theme of biofuels reflects the global preoccupation on the urgency of the use and development of renewable fuels and improved energy technologies. The public perception of the central importance of bioenergy has led many researchers to focus solely on the positive aspects of biofuels thus avoiding their inherent limitations. Their real contribution towards a more sustainable world can only be assessed through a carefully executed approach, as in the practice of cleaner production, which allows investigators to identify its weaknesses and implement improvements in the process in order to avoid and minimize the negative impacts of the production and use of bioenergy.

The practice of eco-innovation is present in $27 \%$ of the articles found in the consulted literature, as improvement to the process of automotive manufacture which minimize the negative impact on the environment, be it through gas emission, reutilization of car carcasses in the manufacturing process, change in the fuel process, among other processes that facilitate innovation.

Figure 11 shows the types of innovation found in the selected articles. Hence, we were able to identify that $97 \%$ of the articles address incremental innovation in their studies, whilst only $3 \%$ present radical innovation. 
Figure 11 - Innovation Types

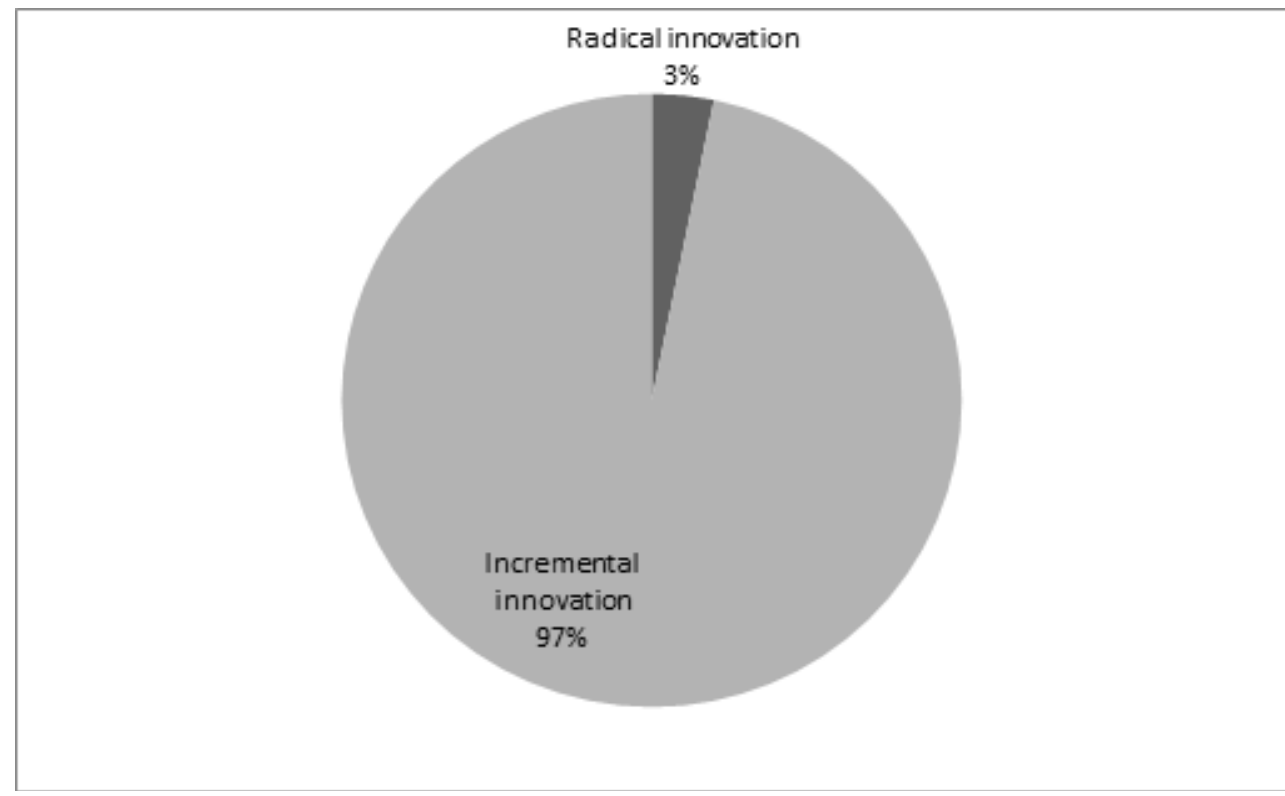

Source: Research data, 2016.

Resta, Gaiardelli and Pezzotta (2009) highlight that manufacturers have also made great strides in improving vehicles fuel efficiency and safety and reducing exhausted emissions, to lower the environmental burden associated with the use phase, through incremental innovations. For instance, the development of hybrid petrol-electric power vehicles, as well as the introduction of new service solutions as car-sharing, whose diffusion can reduce the number of cars by about $40 \%$ and distances driven up to $60 \%$, and supporting the End of Life Vehicle (ELV) take-back initiatives, for example, Design for Disassembly, Design for Dismantling and Design for Recycling methodologies have been introduced to simplify and manage efficiently the disassembling and recovery activities in European companies.

However, Van Den Hoed (2007) explains that the auto industry is not always associated with radical innovation, for complex operations, low margins and high risks tend to favor the process of incremental innovations. The author also stresses that the adoption of radical technology is rare because it requires major changes in skills and automotive operations. However, the radical change in the automotive industry may be required to meet the most stringent environmental standards worldwide. As is the case of the adoption of fuel cell technology (FCV - fuel cell vehicles) that has not materialized yet, HR technology provides an interesting case to study the sources of radical technological change in an established industry. Since the late 1960s the automotive industry has faced increasingly stringent standards, especially related to local gas emissions ( $\mathrm{NOx}, \mathrm{CO}, \mathrm{VOC} 1$ ), the use of fossil fuels and in more recent years greenhouse gases (CO2). Most of the standards set by governments could be met with improved versions of the ICE (internal combustion engine) current or other measures such as developing lightweight constructions or integrate catalyst technologies. That changed in 1990, when the California Air Resources Board (CARB) issued the so-called Zero Emission Vehicles Regulation (ZEV). In the early 1990s the automotive sector increased its investment in alternative propulsion technologies, most notably the BEV (battery electric vehicles) and, to a lesser extent, the hybrid electric vehicle (HEV). Fuel cell vehicles were not considered at the time, and only became relevant in the second half of the 1990s. 
On how innovation impacts on the sustainability of the company, Williams (2006) explains that there is a wide range of environmental problems associated with the automotive industry, including those linked to high levels of resource use in vehicle production and waste materials when the cars reach the end of their useful life. Cars represent the largest source of pollution of the global air, accounting for approximately $30 \%$ of emissions from industrialized countries and $17 \%$ of $\mathrm{CO} 2$ emissions. In the environmental field it has been suggested that, although the efficiency gains obtained as a result of cleaner technologies have reduced emissions, these have been more than offset by increased consumption and more standards of intensive use. It is precisely this kind of "rebound effect" that led many observers to suggest that, for the industry in general, to advance towards long-term sustainability, the change must be facilitated beyond the product or process level innovation and, instead, be conducted on level of the system.

However, many of the initiatives that are currently or have recently been undertaken by actors within the automotive industry have continued to stress the role of technology itself, rather than face the greatest challenges of behavioral changes or system level. The concept of product-service systems (PSS) offers an interesting perspective. This approach suggests that the focus of economic activity should be moved from the manufacture and sale of products and the provision of a whole range of products and services designed to deliver a specific function (Williams, 2007).

Therefore, Williams (2006) suggests that companies can achieve profitable new business opportunities, while simultaneously improving their environmental performance. There are five main environmental impacts of the life cycle associated with manufacturing, use and disposal of vehicles: i) automotive production processes are associated with high levels of resource utilization, sometimes not renewable; ii) there are impacts associated with the use of water and energy in the manufacture and the emissions resulting from energy production; iii) some elements of vehicle construction, especially during metal painting and finishing, result in the emission of pollutants into the air, water and soil; iv) the wide geographic range of the industry means that it must be supported through global logistics and distribution systems, increasing the mileage of transport and exhaust emissions; v) at the end of their lives, vehicles also represent a large waste stream.

In terms of reducing the environmental impact associated with the production, the industry has focused on outsourcing renewable and recycled materials, as well as implementing clean technology and environmental management systems in individual manufacturing sites and throughout the supply chain. Companies have also made efforts to reduce material inputs, changing manufacturing processes to reuse by-products and, where possible, alternative, less toxic materials. By addressing the environmental problems associated with exhaust emissions, some vehicle manufacturers have been motivated to seek technological alternatives to the internal combustion engine (ICE). Initiatives such as the development of fuel cell powered engines, as well as continued research on the use of electric vehicles represent attempts to find alternatives to the current power train technologies. In addition, some companies have developed the hybrid engine technology in an effort to perceive some environmental benefits while continuing to provide consumers with the security of an IC engine. To the extent that the environmental field is concerned, it has been observed that incremental improvements in environmental performance of vehicles are often negatively offset by increases in overall consumption patterns or more intensive use. In this respect, the current economic strategy based on maximizing unit sales and consumption has a direct impact on the overall environmental impact of the industry. Gains in eco-efficiency are more than offset by the fact that more cars are in use (Williams, 2006). 


\section{FINAL CONSIDERATIONS}

This article evidenced, in specialized literature, researches on the theme of sustainable innovation in the automotive sector between 2004 and 2016, through the Scopus database in the CAPES (Coordination for the Improvement of Higher Education Personnel) journals portal.

Thus, through the bibliometric analysis we were able to generate knowledge on the articles, authors, journals, keywords and countries where there is qualified publishing on the theme of sustainable innovation the automotive sector.

We found 31 articles in the Scopus database that aligned with the researched theme. We identified that the most relevant journal on the theme is the Journal of Cleaner Production. The most notable authors were Yamada, T.; Williams; Van den Hoed, R.; Inoue, M. E Bracke, S., which two articles each. The most repeated keywords were Automotive industry, Innovation, Sustainable development and Sustainability, which we established to investigate the database.

It can be concluded through the systemic analysis that the automotive sector is well structure in terms of sustainability and innovation in its process. The innovation promoted by this sector in its processes are incremental, since these are less risky, less expensive and affect less complex operations. However, some authors explain that radical innovations are necessary in order to meet present environmental norms.

The selected studies show that environmental practices employed in the automotive sector are: the minimization of greenhouse gas emissions, life-cycle analysis, cleaner production, reverse logistics and eco-innovation.

It became evident that sustainable innovation in car manufacturing processes, with the practice of gas emission minimization, is in replacing internal combustion engines by fuel cell vehicles (FCV). Technologic innovation of product or manufacturing processes take place in life-cycle practice, for example, the development of hybrid cars - that is, a vehicle composed of an internal combustion engine, usually powered by gasoline, and an electrical engine which enables the reduction of the efforts of the internal combustion engine, thus reducing consumption and emissions. The practice of cleaner production and reverse logistics can be observed in the reuse and recycling of materials in the process. The practice of eco-innovation results in improvements in the car manufacturing process which minimize its negative impact on the environment.

The limitations of this study were: i) the definition of the sample field, since this research used only one database; ii) use of only international work; iii) use of only articles published in journals, excluding theses, dissertations, monographies, conferences and books.

Finally, the recommendations for future research are: i) using of more than one databases from the CAPES portal; ii) considering national databases; iii) using other works, stemming from theses, dissertations, monographies, conferences and books; iv) investigating and identifying the environmental practices in automobile companies' sustainability reports. 


\section{REFERENCES}

Andrews, D. et al. (2006). Black and Beyond: Colour and the Mass- produced Motor Car. Optics and Laser Technology, 38(4-6), 377-391.

Anfavea (2014). Anuário da indústria automobilística brasileira. São Paulo: ANFAVEA.

Anfavea (2006). Indústria automobilística brasileira. São Paulo: ANFAVEA.

Arundel, A.; Kemp, R. (2009). Measuring Eco-Innovation. UNU-MERIT Working Paper Series 017 ,

ning

United Nations University. Netherlands: Maastricht Economic and Social Research and TraiCentre on Innovation and Technology.

Autodata (2011). Terreno Fértil- Setor automotivo intensifica programas e práticas em busca de sustentabilidade. 19(262).

Barbieri, J. C. (2004). Gestão ambiental empresarial. São Paulo: Saraiva.

Barbieri, J. C. (2007). Organizações inovadoras sustentáveis In Barbieri, J. C.; Simantob, M. Organizações inovadoras sustentáveis: uma reflexão sobre o futuro das organizações. São Paulo: Atlas.

Barbieri, J. C.; Simantob, M. (2007). Organizações inovadoras sustentáveis: uma reflexão sobre o futuro das organizações. São Paulo: Atlas.

Barney, J. B; Hesterly, W. S. (2007). Administração estratégica e vantagem competitiva. São Paulo: Prentice-Hall.

Barney, J. B. (1991). Firm resources and sustained competitive advantage. Journal of Management, 17(1), 99-120.

Barros, D. C.; Castro, B. H. R.; Vaz; L. F. H. (2013). Automotivo In BNDES. Perspectivas do investimento 2015 -2018 e panoramas setoriais. Brasília: BNDES, 29-38.

Bastin, C. et al. (2010). Diffusion of New Automotive Technologies for Improving Energy Efficiency in Brazil’s Light Vehicle Fleet. Energy Policy, 38(7), 3586-3597.

Berggren, C.; Magnusson, T. (2012). Reducing Automotive Emissions: The Potentials of Combustion Engine Technologies and the Power of Policy. Energy Policy, 41, 636-643. 
Boons, F. et al. (2013). Sustainable innovation, business models and economic performance: an overview. Journal of Cleaner Production, 45, 1-8.

Braun, J. R. R.; Gomez, L. S. R. (2007). Ecodesign como estratégia de valorização e divulgação de entidades ambientais: a atuação do setor gráfico. Florianópolis: ENSUS. Retrieved from http://www.ensus.com.br/tematica3.

Budde, B. et al. (2012). Expectations as a Key to Understanding Actor Strategies in the Field of Fuel Cell and Hydrogen Vehicles. Technological Forecasting and Social Change, 79(6), 1072-1083.

Carrillo-Hermosilla, J., Del Río, P., Könnola, T. (2009). Eco-innovation: When Sustainability and Competitiveness Shake Hands. London: Palgrave.

Carrillo-Hermosilla, J., Del Río, P., Könnola, T. (2010). Diversity of eco-innovations: Reflections from selected case studies. Journal of Cleaner Production, 18, 1073-1083.

Carson, R. (2002). Silent Spring. Boston: Mariner Books.

Casotti, B. P.; Goldenstein, M. (2008). Panorama do setor automotivo: mudanças estruturais da indústria e as perspectivas para o Brasil. Rio de Janeiro: BNDES.

Christensen, T.B. (2011). Modularised Eco-innovation in the Auto Industry. Journal of Cleaner Production, 19(2), 212-220.

Costa, D. S.; Farias, A. S. D.; Freitas, L. S. (2011). Utilização da eco-inovação no processo de manufatura de cerâmica vermelha In SIMPOI.

Cusumano, M. A.; Nobeoka, K. (1993). Strategy, structure and performance in product development: observations from the auto industries. Research Policy, 21, 265-293.

Elkington, J. (2001). Canibais com garfo e faca. São Paulo: Makron Books.

Falk, J.; Ryan, C. (2006). Investing a sustainable future: Australia and the challenge of ecoinnovation. Futures, 39, 215-219.

Gerard, D.; Lave, L.B. (2005). Implementing Technology-forcing Policies: The 1970 Clean Air Act Amendments and the Introduction of Advanced Automotive Emissions Controls in the United States. Technological Forecasting and Social Change, 72, 761-778.

Gerrard, J.; Kandlikar, M. (2007). Is European End-of-life Vebicle Legislation Living up to Expectations? Assessing the Impact of the ELV Directive on 'Green' lnnovation and Vebicle Recovery. Journal of Cleaner Production. 15(1), 17-27. 
Hoed, R. (2007). Sources of Radical Technological Innovation: The Emergence of Fuel Cell Technology in the Automotive Industry. Journal of Cleaner Production, 15(11), 1014-1021.

Horbach, J.; Rammer, C.; Rennings, K. (2012). Determinants of eco-innovations by type of environmental impact: the role of regulatory push/pull, technology push and market pull. Ecological Economics. 78, 112-122.

Humphrey, J.; Memedovic, O. (2003). The global automotive industry value chain: what prospects for upgrading by developing countries. UNIDO Sectorial Studies Series Working Paper, 2003.

Itacarambi, P. (2012, July 12). O setor automotivo e o desenvolvimento sustentável. Retrieved from http://www3.ethos.org.br/cedoc/o-setor-automotivo-e-o-desenvolvimento-sustentavel/\#. V2veKmNLvcI

Jänicke, M. (2008). Ecological Modernisation: New Perspectives. Journal of Cleaner Production, 16, 557-565.

Kemp, R.; Pearson, P. (Eds) (2008). Final report of the project Measuring Eco- Innovation; Netherlands: Maastricht. Retrieved from http://www.merit.unu.edu/MEI/index.php

Kotler, P. (1996). Administração de Marketing. São Paulo: Atlas.

Lid, Y.; Kokko, A. (2013). Who Does What in China’s New Energy Vehicle Industry? Energy Policy, 57, 21-29.

MDIC (Ministério da Indústria, Comércio Exterior e Serviços) (2016). Introdução: setor automotivo. Retrieved from http://www.mdic.gov.br/sitio/interna/interna.php?area=2\&menu=327

OECD (2009, June). Sustainable manufacturing and eco-innovation: towards a Green economy. Policy Brief .

OECD (1997). The Oslo Manual: The Measurement of Scientific and Technical Activities. Paris: OECD; Eurostat.

Pohl, H.; Yarime, M. (2012). Integrating Innovation System and Management Concepts: The Development of Electric and Hybrid Electric Vehicles in Japan. Technological Forecasting and Social Change, 79(8), 1431-1446.

Prahalad, C. K.; Hamel, G. (1998). A Competência Essencial da Corporação In Montgomery, C. A.; Porter, M. E. Estratégia: a busca da vantagem competitiva. Rio de Janeiro: Campus. 
Pujari, D. (2006). Eco-innovation and new product development: understanding the influences on Market performance. Technovation, 26(1), 76-85.

Schot, J.; Geels, F. W. (2008). Strategic niche management and sustainable innovation journeys: theory, findings, research agenda and policy. Technology Analysis \& Strategic Management, 20(5), $537-554$.

Schulze, A.; Macduffie, J. P.; Täube, F. (2015). A. Introduction: knowledge generation and innovation diffusion in the global automotive industry - change and stability during turbulent times. Industrial and Corporate Change, 1-9.

Sturgeon, T.; Biesebroeck, J. V.; Gereffi, G. (2008). Value chains, networks and clusters: reframing the global automotive industry. Journal of Economic Geography, 8(3), 297-321.

Van den Hoed; R. (2007). Sources of radical technological innovation: the emergence of fuel cell technology in the automotive industry. Journal of Cleaner Production, 15 (11-12), 1014-1021.

Wells, P.; Nieuwenhuis, P. (2012) Transition Failure: Understanding Continuity in the Automotive Industry. Technological Forecasting and Social Change, 79(9),1681-1692. 